
Ana
Vol. VII
comparative cinema
No. 13
Basualdo
2019

\title{
Memory and \\ the river
}

This article takes the reader on a journey through Remembrance Park (the commemorative area in the city of Buenos Aires, which looks onto Río de la Plata, where so many corpses ended up submerged) which intertwines the time of horror with a time that wonders which monuments, which representations can, must, should (?) be erected, practiced, to give substance, body, to what has been taken away. Questions that require us to initiate a dialogue with the fictional works of H.I.J.O.S. (Spanish acronym for Sons and Daughters for Identity and Justice Against Forgetting and Silence, which coincidentally also reads as "children" in Spanish) of the desaparecidos ("missing people") that started to produce their own stories over the last 20 years.

Keywords

HISTORIC MEMORY

REPRESENTATION OF HORROR

FICTION

LITERATURE

ARGENTINA

DESAPARECIDOS

Date of reception: 31/07/2018

Date of acceptance: 17/07/2019

Ana Basualdo (Buenos Aires, 1945) Journalist living in Barcelona since 1975. She is the author of Oldsmobile 1962 (short stories) and Paseos por Barcelona fugitiva. Rastros de la ciudad ácrata (chronicles). The Argentinian publishing house Sigilo is to publish a collection of her journalistic work, titled El presente. 
The water's voice! Juan L. Ortiz.

1. You might not notice it, or confuse it with someone else - an expectant fisherman, some kind of lookout? - who remains still, standing, on what could be a raft or a flooded platform, with his back to the coast, looking at the river. Reconstruction of the portrait of Pablo Miguez (1999-2009) by Claudia Fontes is one of the last sculptures to be placed in Remembrance Park, next to the Río de la Plata. But after a long hour of travelling, I almost missed it: such a solid, figurative sculpture, rocking on a fixed spot (the mooring is invisible) it manages to move - depending on the light and the tides, and depending on the position and circumstances of the visitor - from presence to absence, from absence to presence, every minute that passes, before the river whose limits fade into the horizon. Pablo Míguez was a fourteenyear-old boy when he was kidnapped (he was seen, for a month, at the Navy School of Mechanics, or ESMA, the Spanish acronym), and Claudia Fontes chose him because at that moment, May 12th 1977, she was also fourteen. A "useless" work, extremely human, involving the "reconstructing" Pablo Míguez's presence through an investigation of features that wouldn't be obvious in the piece (the figure would only be seen from afar, with its back turned, amid changing lights), but instead (and specifically), in its ability to "disappear" amongst the mirages and concealments of the river and memory. The sculptor met Míguez's family, interviewed survivors who were imprisoned with him and consulted with the Argentine Forensic Anthropology Team. A thorough reconstruction of details that were impossible to perceive, but necessary: "I like to believe that the final image, the one I'm interested in communicating as an object of memory, in that it is charged with the motivation and intention of the piece, is visually unreachable and is created in the mind of the spectator through the evocation of its traces", she wrote (FONTES in BATTITI 2012: 33). In that work, she plainly described a life-size figure, standing on the water, facing the horizon: "a stainless steel hollowedout statue, mirror polished so that it reflects the color of the Río de la Plata water on its surface". It would be located on a floating platform anchored to the river bed, which would allow it to rock a little because of the waves. The figure would be "like a presence that is revealed by the sparkles of the sunlight that it reflects". A carefully-crafted figure, devised to "recall the physical stance, the energy of someone that age".

2. The Remembrance Park occupies 14 hectares of the city's northern bank, more than 11 kilometers away from Plaza de Mayo, an empty and silent place, unthinkable from the streets of the downtown area - like the river itself. Between the groves of the Ciudad Universitaria area and the Jorge Newbery airport. The park was also designed as a reclining sculpture (undulating, semicircular and with a zig-zag cleft), with tons of dirt and debris from various places: a mixture of traces for future urban archeologists who work on analyzing this artificial riverbank, built upon the continual frenzy of "regaining land from the river". Piling up and spreading dirt, out towards the river, to push it further away. Push it away through vast distances that are difficult to traverse (infrastructures, sports centers, malls, theme parks, luxury housing estates, luxury hotels in old cereal silos and other real estate speculation ideas, ever-covetous of those extendable coasts). Screens like the Catalinas Norte buildings, very eye-catching 
when lit up at night, but imbued with the arrogance and inscrutability of a neoliberal citadel, to the extent that they become repellent. In any case, the Remembrance Park was designed as one piece in a plan that, inversely, promised to incorporate the vast lands of Ciudad Universitaria into urban life, at the very point where the Costanera Norte ends.

As the rules of the international contest stated, memory, represented (architecture, landscaping, sculpture) "without solemnity or fanfare".

\section{Given that it was destined to be} invisible, does the monument produce memory or amnesia? Monuments or anti-monuments? In areas limited by an aura of seriousness, or instead exposed to (and even striving for) pollution and all kinds of social and urban controversies? Is it a subjective, unique, untransferable memory? Or is it abstract, public, exemplary and moral? And what about that memory that has degenerated into a theme park, propaganda, a commodity, retro fashion or academic fashion?

\section{Every trip to Buenos Aires tends} to bear the label of a goal that has to some extent been delayed: this time, it's to see the river. Yesterday, a storm filled my balcony with dry acacia leaves. The trees are already completely bare, but the wind (with rainy spells) still blows in handfuls of leaves, from left to right (facing the river). Though "facing the river" is just an expression: from that point (French and Scalabrini Ortiz, in Palermo) I would have to walk, going straight down, for two and a half kilometers, but right there, at the end of Salguero Street, I would find the almost 20 hectares of the Costa Salguero Center, which since the mid 1990s has occupied the riverfront, with its golf courses, gyms, restaurants, clubs, entertainment venues, conference halls, convention centers, and so on. The river can't be seen, but the water (regardless of whether it rains or not) can be felt everywhere: in pores and cracks, mold, puddles, moss, mud, rust, smells, a proliferation of plants on balconies and rooftops, watering systems, dew, pavements washed down (by janitors) at dawn, the kiosks (one or two per block, open all day and quite a few of them at night) with flowers that have been soaked with sprinklers... "And everything is invaded by the very intense smell of the river" (AnnaKazumi Stahl).

5. In December 1997, 10 Human Rights organizations proposed to the Buenos Aires City Legislature that a monument be constructed to the victims of state terrorism. The proposal was approved by law the following year, duly allocating "a space on the coastline of the Río de la Plata that will be turned into a public path, where a monument will be built together with a multi-sculptural group in homage to those detained-missing (desaparecidos) and murdered by state terrorism". That law was approved, a competition was held, the issue was widely disseminated and debated in the media, universities, academic journals (architecture, philosophy, art, social sciences) and pretty much everywhere because the Trials of the Juntas had already placed, very early on (in May 1985), the disappearance of people within the public sphere of Justice. Obstacles were created later on (the Law of Due Obedience, the Full Stop Law and the pardon decrees), but the appropriation of newborn children - a crime that was deemed imprescriptible - brought everything back to the public eye, and the debates intensified. What to do with the clandestine centers? Should they be a blank slate or a museum, and what kind of museum? How can contemporary art represent or symbolize memory, etc. 
6. Claudia Fontes prepared (or prepared for) her floating sculpture, Reconstruction of Pablo Miguez, through detailed investigations into the body and life of the desaparecido ("missing person"). Architect Alfredo Varas placed particular emphasis on the arduous task of stirring up and kneading the earth and the rubble, molding the park into a kind of semicircular hill that is bare with only a layer of grass and traversed by a zig-zag cleft: the ramps and the four concrete walls of the Monument for the Victims of State Terrorism. Varas talks about that stage of the work as if they had done it with their hands, treating the materials that cannot be seen (the "intractable past", as Beatriz Sarlo called it) as a conscious, voluntary support for the monument. The names, engraved in embossed rectangular porphyry plaques, are within arm's reach. The lists, arranged according to year of disappearance (and each year in alphabetical order) do not reach up to the top of the walls, so that the names can be touched.

7. In the years in which the project was approved (1997) and the park was inaugurated (2007), the trend for commemoration had already spread all over the world (monuments, museums, commemorative places, countless speeches). The start of this trend is usually attributed to the release of the documentary series Shoah (1985), by Claude Lanzmann, and to the advent of the 40th and 50 th anniversaries of wartime events. The Vietnam Veterans Memorial, by Maya Lin, was inaugurated in 1982. The Washington Holocaust Memorial Museum, by James Ingo Freed, in 1993. The Jewish Museum Berlin, by Daniel Libeskind, in 2001. The Nagasaki National Peace Memorial Hall, by Akira Kuryu, in 2003. The Holocaust Museum in Berlin, by Peter Eisenman, in 2005. In all these cases and in that of Argentina, the construction of the object only inflated the existing slew of controversies about how, from where and why a traumatic past should be represented or highlighted. And - given the characteristics of our present - the issue only took minutes to become global and trivial; from Shoah to Schindler's List (Steven Spielberg, 1993) and then on to Life is Beautiful (La vita è bella, Roberto Benigni, 1997), etc. Traumatic or not, "memory has become a cultural obsession of monumental proportions across the globe", wrote Andreas Huyssen (2000: 26).

The river is part of the Buenos Aires monument, whose zigzag cleft is similar to the lightning bolt design of Jewish Museum Berlin. Here the lightning bolt points to the river. The monument crosses the park, between the straight line of a pedestrian path that separates it from the city and the curved line of the path by the river: "The memory of the desaparecidos lies between those lines: between Buenos Aires and the Río de la Plata".

8. And it could be said that the idea of a Remembrance Park came from the river itself: from this photo that Marcelo Brodsky took from a boat, early in the morning, crossing to Uruguay.

During an exhibition at the National School of Buenos Aires, standing in front of a huge enlargement of this photo, the group of alumni to which Brodsky belongs became the promoters of a Remembrance Park (with sculptures; the monument came later) on the banks of the river. Together with the Student Center and relatives of the disappeared people (there were 105 from the National School) they applied to human rights organizations, which donated a memorial to the sculpture park with the names of the desaparecidos. "We put together the two ideas", says Brodsky, "and we presented the project to the Buenos 


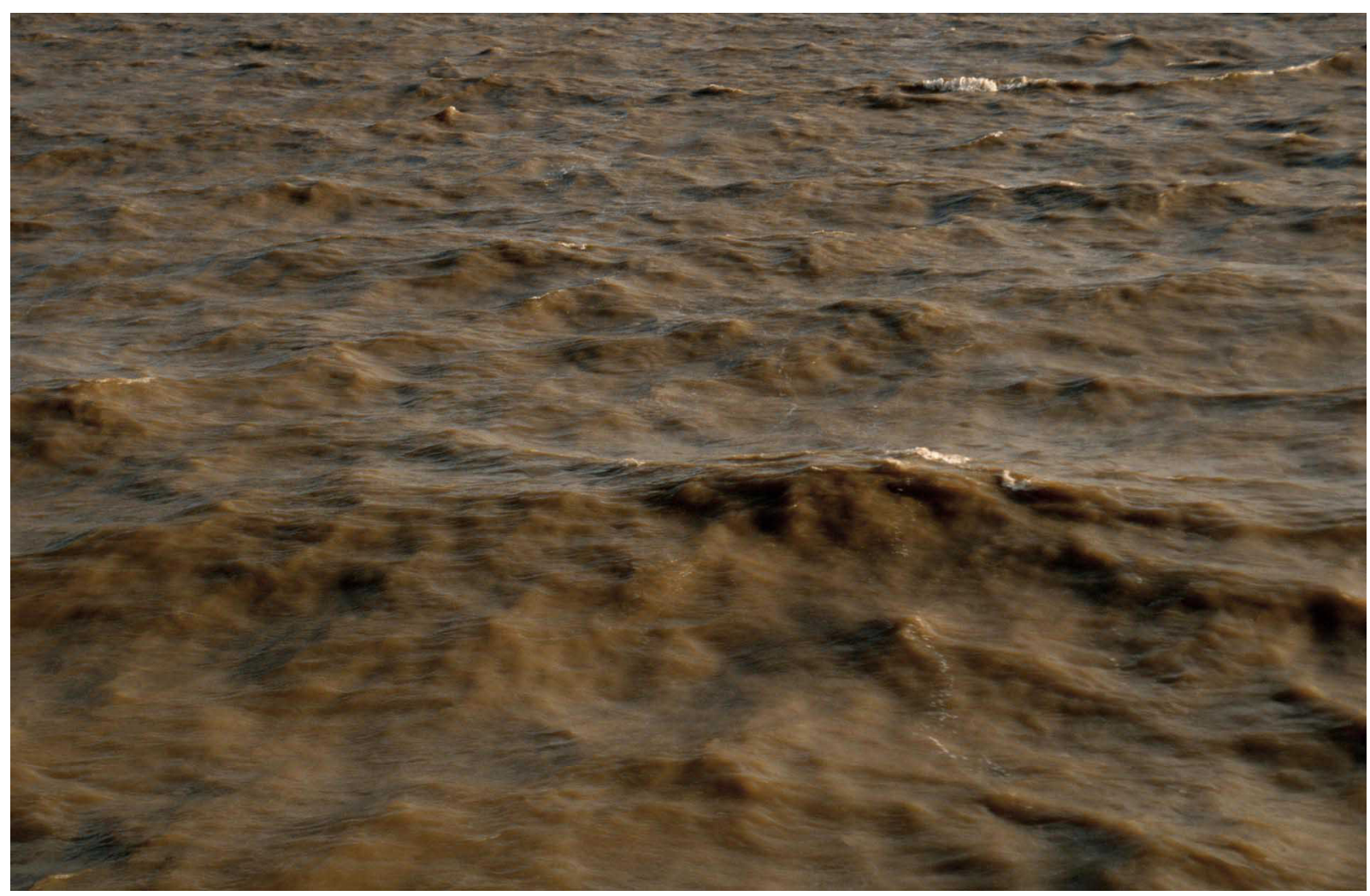

El Río de la Plata (Marcelo Brodsky, 1997)

Aires City Legislature"1. By the way, it was not the political parties or any of the other inane institutions; it was human rights organizations that, during the euphoria of the World Cup and the Falklands War, released news on the disappearance of people. That loneliness is also what the park is commemorating.

I went there by bus, through the forests of Palermo, along seventymeter wide avenues, passing beneath the green iron and exposed brick bridges of the Mitre Railway, bordering tennis courts and golf courses. There's no one there. It is fall: early June, midmorning on Wednesday. I get off at Ciudad Universitaria. Cars parked under the trees, gravel paths, a few students going up the stairway of the Faculty of Exact Sciences. The first person I ask gets it wrong, directing me straight to the river and then to the right, where a chain-link fence blocks my path, among grassland that reaches up to my waist. The second person points me to a street that winds between eucalypti and storehouses, and which leads into the side path of the park. Young maples in gray gravel quadrilaterals stand at the entrance. The hill, green, bare and empty. The semicircular coast is outlined above the river plain, where nothing seems to be moving, from here to the horizon. There's no one on the ramps. The sun is only shining fully on the first mural, which begins underground (like the Vietnam Veterans Memorial) and now has the same streaky brown color as the river. The choice of this spot has been widely criticized: for being far away, inaccessible, forgotten and sinister (equidistant from the Navy School of Mechanics and the airfield, from which the so-called "death flights" took off). However, there doesn't seem to be any better place available. Especially if the city decided (there'd be lots of obstacles to remove) to move closer to the river.

\section{Apart from monuments: there's} the museification of places of detention and torture, the ritualized placement of commemorative paving stones, autobiographical stories, novels, movies, and so on. Does 
the excess of memory (Funes the Memorious is quoted time and time again in articles, essays, dissertations, etc.) hinder our understanding? Does memory have a purifying function? Is there anything specific about the case of Argentina? The Nunca más ("Never Again") report by CONADEP (Spanish acronym for National Commission on the Disappearance of Persons) and the trials outlined - through the testimonies of the survivors - the initial topography of the concentration camps, and the hierarchical and clandestine way in which they operated. Personal-experience testimonies became evidence. The legal procedure "rewrote" the stories by classifying them, comparing them and linking them. And in this network of references, names were revealed, scenes repeated and clues converged: through the legal appraisal of surviving witnesses, the victims turned into legal subjects, set against the accused soldiers.

10. Memory: distancing. Two books. In 1998, an essential study was published on concentration camps in Argentina, written by Pilar Calveiro, a former montonera who was kidnapped in 1977 and held in several camps, including ESMA. Released in 1979, she was fleetingly exiled in Spain and then Mexico, where she gained a doctorate in political science. She wrote Poder y desaparición ("Power and Disappearance") in the third person, which is particularly important because (although the testimonies are the basis of her work) it conveys the conviction that the extreme experience of the camp does not guarantee that it can be understood. She doesn't write as if she hadn't been there, artificially concealing that she was: she leaves out her personal suffering because it will be expressed or absorbed anyway by what others say and, above all, because, by distancing herself in that way, she's in a better position to analyze the bureaucratic manner in which state terrorism operates, the rationale of torture, the system of relations between that underworld ("the well", "the operating room", "the Olympus", "the Pearl", etc.) and the visible power and the people who walked along the street.

It's a great achievement, undertaken by a woman who belongs to the main generation in the list of victims. Meanwhile, Mariana Eva Perez (no written accent), born in 1977, fifteen months before her parents were abducted, wrote her own account, using other methods and tools for establishing a distanced view. In Diario de una Princesa Montonera ("Montonera Princess Diary"), her memoirs are rendered using caution, hard work, modesty, urgency, an allergy to emotional blackmail, joking irony, black humor, quips that mock the generational way of speaking and the rhetoric of H.I.J.O.S. (the narrator spells it as "hijis"). Unless memory is twisted into a commercial or manipulating obscenity (a curse common to everything, without doubt), how can the "excess" of memories be measured if this type of orphans exists? The only thing Mariana Eva Perez remembers about her first house, in Palermo, is "something orange". Victims of a remote projection. Like Virginia Ogando, the daughter of desaparecidos and the sister of a stolen child, whom she failed to find: a stranger to whom, before committing suicide a few years ago, she left an envelope containing seven letters. The novel The Moles (Los topos), by Félix Bruzzone, which appeared in 2008, moves into ghostly territory, as illustrated by the poet and critic Edgardo Dobry at the seminar "Cinema as a weapon", held by the Universitat Pompeu Fabra in Barcelona, on the concept of genocide as being erroneously applied to the killings in Argentina during those years: 
"Videla and company military savagery was a massacre and a crime against humanity, but not genocide. The proof, if we need it, resides precisely in the existence of the recovered grandchildren. No Nazi hierarch would have thought of keeping or 'giving away' a Jewish baby: they had to be eliminated so as not to contaminate the race. Instead, the children of the communists and guerrilla fighters could be 'redeemed' of an origin of which they were innocent (and here the sordid Catholic support for murderers and baby thieves comes into play). On the other hand, genocide, in its desire to eliminate all the individuals of a whole 'race' or nation, demands mass slaughter and leaves, in the end, 'iconic' images of piles of corpses (such as the ones that shocked Susan Sontag when she discovered by chance, in a New York bookstore, the photos taken by the first allied soldiers who entered Sobibor and Bergen-Belsen). The Argentinian dictatorship, however, did not leave visible corpses; the hidden corpses or the ones thrown into the river are the ones that Perlongher sees everywhere, ghostly in appearance, in his famous poem 'Cadáveres' ('Corpses', a poem charged with the kind of domestic eroticism that impregnates much of his work). My idea is that those bodies that are not here reappear in the depraved enjoyment of the books of the H.I.J.O.S.: in the encounter between the montonera princess and the mysterious man who was her mother's lover, in the uncontrollable drive that leads the boy in The Moles to seek sex with transsexuals: there is an excess of physicality, as if the stolen, hidden, desaparecido body reappeared there".

\section{At the end of the ramp that} goes up, turns and descends across the artificial hill, half-buried at the northern end of the coastal semicircle, in a gray building (which reminds me of the Mies Pavilion in Barcelona) there is a computerized documentation center operated by the Faculty of Exact Sciences and exhibition halls. Now, in August, seven of Bill Viola's video installations are being shown, brought together especially to be exhibited here: The Passing, The Messenger, Surrender, Observance, Three Women, Ancestors and Acceptance. Underwater bodies at the very edges of invisibility and regeneration, fluctuating from an eye of light that emits jets of milky clarity.

Text published, in an earlier version, in $\mathrm{La}$ Maleta de Portbou, November-December 2013.

Translated by Daniela Torres Montenegro (See original text at the end of the journal)

\section{Further reading}

Nunca más. Informe final de la Comisión Nacional sobre la Desaparición de Personas (CONADEP, 1984). The last edition, from 2012, includes a new prologue, signed by the Human Rights Secretariat of the Nation, which precedes the original one and caused controversy. The earlier prologue had adhered to the theory of "the two demons": the guerrilla and the state system of torture and the disappearance of people. On this subject, read: La historia política del Nunca Más. La memoria de las desapariciones en la Argentina, by Emilio Crenzel (2008). See also Crenzel's article Papeles de la memoria. La historia del informe Nunca más (2010). 
1/ The Board of the Park is composed, by law, of the following organizations: Grandmothers of the Plaza de Mayo, Permanent Assembly for Human Rights, Buena Memoria Civil Association, Center for Legal and Social Studies, Relatives of Disappeared and Detained for Political Reasons, Argentinian Historical and Social Memory Foundation, Mothers of Plaza de Mayo Founding Line, Ecumenical Movement for Human Rights, and Peace and Justice Service.

\section{Bibliography}

BATTITI, Florencia (2012). El arte ante las paradojas de la representación. Cuadernos del Centro de Estudios en Diseño y Comunicación, 41, pp. 29-40.

CALVEIRO, Pilar (1998). Poder y desaparición. Los campos de concentración en Argentina. Buenos Aires: Colihue.

CONAPEP (1984). Nunca Más. Informe final de la Comisión Nacional sobre la Desaparición de Personas. Buenos Aires: Editorial Universitaria de Buenos Aires.

CRENZEL, Emilio (2008). La historia política del Nunca Más. La memoria de las desapariciones en la Argentina. Buenos Aires: Siglo XXI.

CRENZEL, Emilio (2010). Papeles de la memoria. La historia del informe Nunca más. Papeles del CEIC, 2, pp. 1-3. Available in: http://www.redalyc.org/ pdf/765/76517019005.pdf [access: July 7th 2019]

HUYSSEN, Andreas (2000). Present Pasts: Media, Politics, Amnesia. Public Culture, 12(1), pp. 21-38.

SAER, Juan José (1991). El río sin orillas. Tratado imaginario. Madrid: Alianza.

SARLO, Beatriz (2012). Tiempo pasado. Buenos Aires: Siglo XXI.

TODOROV, Tzvetan (2000). Los abusos de la memoria. Barcelona: Paidós

VERBITSKY, Horacio (2004). El vuelo. Buenos Aires: Editorial Sudamericana

VEZZETTI, Hugo

(2002). Pasado y presente. Guerra, dictadura y sociedad en la Argentina.

Buenos Aires: Siglo XXI

(2007). Conflictos de la memoria en la Argentina. Un estudio histórico de la memoria social. PÉROTIN-DUMON, Anne (dir.), Historizar el pasado vivo en America Latina. Available in: http://americo.usal.es/iberoame/sites/default/files/ vezzetti_conflictos_memoria_argentina.pdf [access:July 7th, 2019]

VVAA (2000). Revista Punto de vista, 68.

ARFUCH, Leonor. Arte, memoria y archivo (pp. 34-37).

HUYSSEN, Andreas. El Parque de la Memoria. Una glosa desde lejos (pp. 25-28).

RICHARDS, Nelly. Memoria, fotografía y desaparición: drama y tramas (pp. 29-33).

SCHMUCLER, Héctor. Las exigencias de la memoria (pp. 5-9).

SILVESTRI, Graciela. En arte en los límites de la representación (pp. 18-24). TERÁN, Oscar. Tiempos de memoria (pp. 10-12).

VEZZETTI, Hugo. Representaciones de los campos de concentración en la Argentina (pp. 13-17). 

Ana
Vol. VII
comparative cinema
No. 13
Basualdo
2019

\section{La memoria y el río}

El presente artículo propone un recorrido por el Parque de la Memoria (espacio conmemorativo de la ciudad de Buenos Aires, abierto hacia el Río de la Plata, donde tantos cadáveres terminaron sumergidos), que entrecruza el tiempo del horror con uno que se pregunta qué monumentos, qué representaciones se pueden, se deben, ¿se deberian?, erigir, ensayar, para dar cuerpo a lo sustraído. Preguntas que entablan un necesario diálogo con las ficciones de los H.I.J.O.S. (Hijos e Hijas por la Identidad y la Justicia contra el Olvido y el Silencio) de los desaparecidos que comenzaron a producir sus propios relatos en los últimos veinte años.

Palabras Clave

MEMORIA HISTÓRICA

REPRESENTACIÓN DEL HORROR

FICCIÓN

LITERATURA

ARGENTINA

DESAPARECIDOS

Fecha de recepción: 31/07/2018

Fecha de aceptación: 17/07/2019

Ana Basualdo (Buenos Aires, 1945) Periodista. Desde 1975 reside en Barcelona. Es autora de los

libros Olsmobile 1962 (cuentos) y Paseos por Barcelona fugitiva. Rastros de la ciudad ácrata (crónicas). Una recopilación de su trabajo periodístico se publicará, con el título El presente, en la editorial argentina Sigilo. 

2012: 33). Allí anunciaba, escuetamente, una figura de tamaño real, de pie so-

1. Podría uno no advertirla, o confundirla con alguien - ¿un pescador expectante, una especie de vigía?- que permanece inmóvil, de pie, en lo que podría ser una balsa o una plataforma inundada, de espaldas a la costa, mirando el río. Reconstrucción del retrato de Pablo Míguez (1999-2009), de Claudia Fontes, es una de las últimas esculturas emplazadas en el Parque de la Memoria, a orillas del Río de la Plata. Pero, tras una hora larga de recorrido, casi me la pierdo: tal escultura sólida, figurativa, balanceante sobre un punto fijo (el amarre es invisible) logra transitar, según la luz y las mareas y según la posición y circunstancias del visitante, de la presencia a la ausencia, de la ausencia a la presencia, cada minuto que pase, ante el río cuyos límites se confunden con el horizonte. Pablo Míguez era un chico de catorce años, cuando lo secuestraron (fue visto, durante un mes, en la ESMA), y Claudia Fontes lo eligió porque en ese momento, 12 de mayo de 1977, ella también tenía catorce años. Un trabajo «inútil», empeñosamente humano, de "reconstruir» la presencia de Pablo Míguez a través de una investigación de rasgos que no resultarían notorios en la obra (la figura solo se vería de lejos, de espaldas, entre luces cambiantes) sino, justamente, en su capacidad de "desaparecer» entre los espejismos y ocultamientos del río y de la memoria. La escultora conoció a la familia Míguez, entrevistó a sobrevivientes que compartieron con él cautiverio y consultó con el Equipo Argentino de Antropología Forense. Reconstrucción minuciosa de detalles imposibles de advertir, pero necesarios: «Me gusta creer que la imagen definitiva, la que me interesa comunicar como objeto de memoria, en tanto está cargada de la motivación e intención del trabajo, es visualmente inaccesible y se crea en la mente del espectador mediante la evocación de bre el agua, de cara al horizonte: «una escultura vaciada en acero inoxidable, pulida espejo, de tal manera que refleje el color del agua del Río de la Plata en su superficie». Se ubicaría sobre una plataforma flotante anclada al lecho del río, dejándola balancear una pizca por el oleaje. La figura sería «como una presencia que se descubre por los destellos de luz del sol que pueda reflejar». Una figura trabajada de cerca, a fin de "recuperar la actitud corporal, la energía de alguien de esa edad».

\section{El Parque de la Memoria ocupa} catorce hectáreas de la ribera norte de la ciudad, a más de once kilómetros de Plaza de Mayo, en un lugar vacío y silencioso, impensable desde las calles del centro -como el propio río-. Entre las arboledas de la Ciudad Universitaria y el aeropuerto Jorge Newbery. El parque fue modelado, también, como una escultura acostada (ondulada, semicircular, con una hendidura en zig-zag), con toneladas de tierra y escombros de procedencia diversa: mezcla de rastros para arqueólogos urbanos del futuro que se dediquen a analizar esta ribera artificial, construida sobre el delirio continuado de "ganarle terreno al río». Amontonar y estirar escombros, hacia el río, para alejarlo más. Alejarlo a través de distancias kilométricas difíciles de transitar (infraestructuras, polideportivos, centros comerciales, parques temáticos, urbanizaciones de lujo, hoteles de lujo en antiguos silos cerealeros y demás ocurrencias de la especulación inmobiliaria, codiciosa desde siempre de esas costas extensibles). Pantallas como los edificios de Catalinas Norte, muy vistosos iluminados en la noche pero plantados con una altanería y un hermetismo de ciudadela neoliberal, que repelen. El Parque de la Memoria, en todo caso, se proyectó como pieza de un plan que prometía, 
al revés, incorporar a la vida urbana los amplios terrenos de la Ciudad Universitaria, allí donde acaba la Costanera Norte.

La memoria, decían las bases del concurso internacional convocado, representada (arquitectura, paisajismo, escultura) "sin solemnidades ni estridencias».

3. Ya que la invisibilidad sería su destino, ¿es memoria o amnesia lo que produce el monumento? ¿Monumentos o anti-monumentos? ¿En ámbitos limitados por un aura de gravedad o expuestos a contaminaciones y controversias urbanas y sociales de todo tipo, e incluso afanosos de ellas? ¿Se trata de una memoria subjetiva, única, intransferible? ¿O abstracta, pública, ejemplar, moral? ¿Y la memoria degenerada en parque temático, propaganda, mercancía, moda retro, moda académi$\mathrm{ca}$ ?

\section{Cada viaje a Buenos Aires suele} llevar la etiqueta de algún propósito más o menos postergado: esta vez, ver el río. Ayer, un temporal llenó el balcón de hojas secas de las acacias. Los árboles están pelados del todo ya, pero el viento (con rachas de lluvia) sigue mandando andanadas de hojas, de izquierda a derecha (mirando el río). Es un decir, mirando el río: desde este punto -French y Scalabrini Ortiz, en Palermotendría que caminar, bajando recto, dos kilómetros y medio, pero justo ahí, al final de la calle Salguero, me toparía con las casi veinte hectáreas del Centro Costa Salguero, que ocupan -desde mediados de los noventa- el frente del río con sus campos de golf, gimnasios, restaurantes, discotecas, salas de espectáculos, congresos, convenciones... El río no se ve, pero el agua (llueva o no) se siente por todas partes: en poros y grietas, moho, charcos, verdines, barro, óxido, olores, proliferación vegetal en balcones y azoteas, riego, rocío, las aceras lavadas (por los conserjes) al amanecer, los kioscos de flores (uno o dos por manzana, abiertos todo el día y no pocos de noche) mojadas con rociador... "Y todo lo invade el olor a río, bien intenso» (Anna-Kazumi Stahl).

5. En diciembre de 1997, diez organismos de Derechos Humanos propusieron a la Legislatura de la Ciudad Autónoma de Buenos Aires la construcción de un monumento a las víctimas del terrorismo de Estado. La propuesta se aprobó, por ley, al año siguiente, destinando «en la franja costera del Río de la Plata un espacio que será afectado como paseo público, donde se emplazará un monumento y un grupo poliescultural en homenaje a los detenidos-desaparecidos y asesinados por el terrorismo de Estado». Pudo aprobarse esa ley, llamarse a concurso, difundirse y debatirse el asunto caudalosamente en la prensa, en universidades, en revistas especializadas (arquitectura, filosofía, arte, ciencias sociales) y un poco por todos lados porque los Juicios a las Juntas ya habían ubicado, muy pronto -desde mayo de 1985- la desaparición de personas en el terreno público de la Justicia. Se pondrían luego obstáculos (las leyes de obediencia debida y punto final y los decretos de indulto) pero la apropiación de recién nacidos -crimen declarado imprescriptible- llevó todo a escena otra vez, y profundizó los debates. Qué hacer con los centros clandestinos: tabla rasa o museo, y qué tipo de museo. Cómo el arte contemporáneo puede representar o simbolizar la memoria...

6. Claudia Fontes preparó (o se preparó para) su escultura flotante, Reconstrucción de Pablo Míguez, con averiguaciones al pormenor sobre el cuerpo y la vida del desaparecido. Y el arquitecto Alfredo Varas le ha dado un valor explícito al trabajo arduo de remover y amasar tierra con escom- 
bros, moldeando el Parque en forma de colina semicircular, desnuda con solo una capa de hierba y atravesada por una hendidura zigzagueante: las rampas y los cuatro muros de hormigón del Monumento a las víctimas del terrorismo de Estado. Varas habla de esa etapa de la obra como si el trabajo lo hubieran hecho con las manos, tratando los materiales que no se ven («el pasado intratable», como dijo Beatriz Sarlo) como sostén consciente, voluntario del monumento. Los nombres, grabados en placas rectangulares de pórfido, en relieve, están al alcance de la mano. Las listas, ordenadas por año de desaparición (y cada año por orden alfabético) no llegan a la franja alta de los muros, para que los nombres puedan tocarse.

\section{En los años en que se aprobó el} proyecto (1997) y el Parque se inauguró (2007), ya se había extendido sobre todo por el mundo la corriente memorialística (monumentos, museos, lugares conmemorativos, discursos innúmeros) cuyo arranque suele atribuirse a la difusión de la serie Shoah (1985), de Claude Lanzmann, y a la sucesión de cuadragésimos y quincuagésimos aniversarios de hechos de la guerra. El Vietnam Veterans Memorial, de Maya Lin, se inauguró en 1982. El Museo del Holocausto de Washington, de James Ingo Freed, en 1993. El Museo Judío de Berlín, de Daniel Libeskind, en 2001. El Nagasaki National Peace Memorial Hall, de Akira Kuryu, en 2003. El Museo del Holocausto de Berlín, de Peter Eisenman, en 2005. Tanto en estos casos como en el argentino, la construcción del objeto abultó un archivo de polémicas sobre cómo, desde dónde, para qué representar o señalar un pasado traumático. Y -dados los rasgos de nuestro presente- el asunto tardó minutos en volverse global y trivial: de Shoah a La lista de Schindler (Schindler's List, Steven Spielberg, 1993) y de ahí a La vida es bella (La vita è bella, Roberto Benigni, 1997)... Traumática o no, «la memoria se ha convertido en una obsesión cultural de monumentales proporciones en el mundo entero", escribió Andreas Huyssen.

El río es parte del monumento porteño, cuyo zigzagueo se asemeja al volumen en forma de rayo del Museo Judío de Berlín. Aquí el rayo apunta al río. El monumento atraviesa el parque, entre la línea recta de un sendero peatonal que separa de la ciudad y la línea curva del paseo sobre el río: «La memoria de los desaparecidos yace entre esas líneas: entre Buenos Aires y el Río de la Plata».

8. Y la idea de un Parque de la Memoria surgió, podría decirse, del propio río: de esta foto que Marcelo Brodksy tomó desde un barco, por la mañana temprano, cruzando al Uruguay.

En el curso de una exposición en el Colegio Nacional de Buenos Aires, delante de una ampliación gigante de esta foto, el grupo de exalumnos del que Brodsky forma parte se constituyó en impulsor de un Parque de la Memoria (con esculturas; el monumento llegó después) a orillas del río. Junto con el Centro de Estudiantes y con familiares de desaparecidos (fueron 105, en el Colegio Nacional) acudieron a las organizaciones de derechos humanos, que añadieron al parque de esculturas un memorial con los nombres: «Juntamos las dos ideas - dice Brodsky-y presentamos el proyecto a la Legislatura de la Ciudad de Buenos Aires» ${ }^{1}$. A propósito: no fueron los partidos políticos ni demás instituciones inanes entonces sino los organismos de derechos humanos los que, durante la euforia del Mundial de Fútbol y la guerra de las Malvinas, dieron noticias sobre la desaparición de personas. Aquella soledad es lo que el Parque memoriza, también.

Fui en colectivo, a través de los bosques de Palermo, por avenidas de setenta metros de ancho, pasando por debajo de los puentes de hierro verde y 
ladrillo visto del Ferrocarril Mitre, bordeando canchas de tenis y campos de golf. No hay nadie. Es otoño: principios de junio, media mañana de miércoles. Me bajo en la Ciudad Universitaria. Coches estacionados bajo los árboles, caminos de pedregullo, estudiantes escasos subiendo las escalinatas de la Facultad de Ciencias Exactas. El primero al que le pregunto se equivoca, al señalarme recto hacia el río y luego a la derecha, donde se interpone una valla de alambre, entre pastizales que me llegan a la cintura. El segundo me envía a una calle sinuosa, entre eucaliptos y galpones, que desemboca en el paseo lateral del parque. Arces jóvenes en cuadriláteros de grava gris, en la entrada. La colina verde y desnuda, vacía. La costa en semicírculo se recorta sobre la planicie del río, donde no parece moverse nada de aquí al horizonte. En las rampas no hay nadie. El sol se estampa de pleno solo en el primer mural, que arranca subterráneo (como el Vietnam Veterans Memorial) y tiene ahora el mismo color marrón veteado del río. Mucho se criticó la elección de este lugar: lejano, inaccesible, olvidado, siniestro (equidistante de la Escuela de Mecánica de la Armada y del Aeroparque, de donde despegaban los llamados "vuelos de la muerte»). No parece, sin embargo, que exista lugar mejor. Sobre todo si la ciudad decidiera (mucho tipo de obstáculo habría de derribar) venir al río.

9. Además de monumentos: museificación de los sitios de detención y tortura, colocación ritualizada de baldosas conmemorativas, relatos autobiográficos, novelas, películas... ¿El exceso de memoria (Funes el memorioso es citado una y otra vez en artículos, ensayos, tesinas, etc.) bloquea el entendimiento? ¿Tiene función purificadora la memoria? ¿Tiene algo de específico el caso argentino? El informe Nunca más de la CONADEP (Comisión Nacional sobre la Desaparición de Personas) y los Juicios esbozaron, a través de testimonios de supervivientes, la primera topografía de los campos de concentración, su funcionamiento jerarquizado y clandestino. Testimonios de experiencias personales fueron constituidos en pruebas. El procedimiento jurídico "reescribía» los relatos al clasificarlos, compararlos, relacionarlos. Y en esa red de referencias quedaban prendidos nombres, escenas repetidas, pistas convergentes: las víctimas, a través de la valoración jurídica de testimonios de supervivientes, se volvieron sujetos de derecho, frente a los militares acusados.

10. Memoria: tomas de distancia. Dos libros. En 1998, se publicó un estudio imprescindible sobre los campos de concentración en Argentina, escrito por Pilar Calveiro, una exmilitante montonera secuestrada en 1977 y recluida en varios campos, entre ellos la ESMA. Liberada en 1979, se exilió fugazmente en España y luego en México, donde se doctoró en ciencias políticas. Escribió Poder y desaparición en tercera persona, lo cual importa sobre todo porque (aunque el sustento del trabajo sean los testimonios) trasmite la convicción de que la experiencia límite del campo no garantiza su entendimiento. No es que hable como si no hubiera estado allí, ocultando artificiosamente que estuvo: omite su padecimiento personal ya que, en todo caso, se va a reflejar o a quedar absorbido en el de otros y, sobre todo, porque -tomada esa distanciaestá en mejor posición para analizar el funcionamiento burocrático del terrorismo de Estado, la lógica de la tortura, el sistema de relaciones entre ese submundo («el pozo», "el quirófano», "el Olimpo», "la Perla»...) y el poder visible y la gente que andaba por la calle.

Es una proeza, acometida por una mujer que pertenece a la generación mayoritaria en la lista de víctimas. Con otras maniobras y herramientas para tomar distancia escribió el suyo Mariana Eva Perez (sin acento), que nació 
en 1977, quince meses antes de que secuestraran a sus padres. En Diario de una Princesa Montonera, la memoria es perseguida con cautela, trabajo, pudor, urgencia, alergia al chantaje sentimental, ironía jocosa, humor negro, estridencias burlonas del habla generacional y de la retórica de H.I.J.O.S. (la narradora escribe "hijis»). Salvo si la memoria es desviada (un maleficio, sin duda, común a todo...) a lo obsceno mercantil o manipulador, ¿cómo se mide el «exceso» de recuerdos si existe esta clase de huérfanos? Lo único que Mariana Eva Perez recuerda de su primera casa, en Palermo, es «algo anaranjado». Víctimas de proyección remota. Como Virginia Ogando, una hija de desaparecidos y hermana de un niño robado, a quien no logró encontrar: un extraño al que, antes de suicidarse, hace unos años, le dejó un sobre con siete cartas. Aparecida en 2008, la novela Los topos, de Félix Bruzzone, avanza en territorio fantasmal, que el poeta y crítico Edgardo Dobry ha iluminado así, en la «Jornada Internacional el cine como arma» organizada por la Universitat Pompeu Fabra en Barcelona, en relación al concepto de genocidio aplicado, erróneamente, a la matanza de aquellos años en la Argentina:

"Lo de los salvajes militares de Videla y compañía fue una masacre y un crimen de lesa humanidad, pero no un genocidio. La demostración, si hace falta, reside precisamente en la existencia de los nietos recuperados. A ningún jerarca nazi se le hubiera ocurrido quedarse con o "regalar" un bebé judío: debían ser eliminados para no contaminar la raza. En cambio, los hijos de los comunistas y guerrilleros podían ser "redimidos" de un origen del que no eran culpables (ahí entra el sórdido amparo católico de los asesinos y ladrones de bebés). Por otra parte, el genocidio, por su voluntad de eliminar a todos los individuos de toda una "raza" o nación, exige la ma- tanza a gran escala y deja, al final, imágenes "icónicas" de cadáveres apilados (como las que impresionan a Susan Sontag cuando descubre por casualidad, en una librería de Nueva York, las fotos que tomaron los primeros soldados aliados que entraron en Sobibor o Bergen-Belsen). En cambio, la dictadura argentina no deja cadáveres visibles; precisamente, esos cadáveres ocultos o arrojados al río son los que, fantasmagóricos, ve Perlongher por todas partes en su famoso poema "Cadáveres" (un poema cargado de esa suerte de erotismo doméstico que impregna buena parte de su obra). Mi idea es que esos cuerpos que no están reaparecen en el goce perverso de los libros de los H.I.J.O.S.: en el encuentro de la princesa montonera con el misterioso hombre que fue amante de su madre, en la pulsión irrefrenable que lleva al chico de Los topos a buscar sexo con transexuales: hay un exceso de fisicidad, como si ahí reapareciera el cuerpo sustraído, ocultado, desaparecido".

11. Al final de la rampa que sube, dobla y baja a través de la colina artificial, semienterrado en el extremo norte del semicírculo costero, en un edificio gris (que me recuerda el Pabellón de Mies en Barcelona) funciona un centro de documentación computarizado por la Facultad de Ciencias Exactas y salas de exposiciones. Ahora, en agosto, se muestran siete videoinstalaciones de Bill Viola, reunidas a propósito para ser exhibidas aquí: The Passing, The Messenger, Surrender, Observance, Three Women, Ancestors, Acceptance. Cuerpos subacuáticos en el límite de la invisibilidad y la regeneración, oscilantes desde un ojo de luz a chorros de claridad lechosa.

Texto publicado, en una versión anterior, en La Maleta de Portbou, noviembrediciembre 2013. 
Nunca Más. Informe final de la Comisión Nacional sobre la Desaparición de Personas (CONADEP, 1984). La última edición, de 2012, antepone al original un prólogo firmado por la Secretaría de Derechos Humanos de la Nación, lo cual desató polémicas. El primer prólogo adhiere a la teoría de «los dos demonios»: la guerrilla y el sistema estatal de tortura y desaparición de personas. Al respecto, puede leerse: La historia política del Nunca Más. La memoria de las desapariciones en la Argentina, de Emilio Crenzel (2008). También de Emilio Crenzel, el artículo Papeles de la memoria. La historia del informe Nunca más (2010).

1/ El Consejo de Administración del Parque está integrado, por ley, por los siguientes organismos: Abuelas de Plaza de Mayo, Asamblea Permanente por los Derechos Humanos, Buena Memoria Asociación Civil, Centro de Estudios Legales y Sociales, Familiares de Desaparecidos y Detenidos por Razones Políticas, Fundación Memoria Histórica y Social Argentina, Madres de Plaza de Mayo Línea Fundadora, Movimiento Ecuménico por los Derechos Humanos y Servicio de Paz y Justicia.

\section{Referencias bibliográficas}

BATTITI, Florencia (2012). El arte ante las paradojas de la representación. Cuadernos del Centro de Estudios en Diseño y Comunicación, 41, pp. 29-40. CALVEIRO, Pilar (1998). Poder y desaparición. Los campos de concentración en Argentina. Buenos Aires: Colihue.

CONAPEP (1984). Nunca Más. Informe final de la Comisión Nacional sobre la Desaparición de Personas. Buenos Aires: Editorial Universitaria de Buenos Aires.

CRENZEL, Emilio (2008). La historia política del Nunca Más. La memoria de las desapariciones en la Argentina. Buenos Aires: Siglo XXI.

CRENZEL, Emilio (2010). Papeles de la memoria. La historia del informe Nunca más. Papeles del CEIC, 2, pp. 1-3. Disponible en: http://www.redalyc.org/ pdf/765/76517019005.pdf [acceso: 7 de julio de 2019]

HUYSSEN, Andreas (2002). En busca del futuro perdido. Cultura y memoria en tiempo de globalización. México D.F.: Fondo de Cultura Económica.

SAER, Juan José (1991). El río sin orillas. Tratado imaginario. Madrid: Alianza.

SARLO, Beatriz (2012). Tiempo pasado. Buenos Aires: Siglo XXI.

TODOROV, Tzvetan (2000). Los abusos de la memoria. Barcelona: Paidós

VERBITSKY, Horacio (2004). El vuelo. Buenos Aires: Editorial Sudamericana VEZZETTI, Hugo

(2002). Pasado y presente. Guerra, dictadura y sociedad en la Argentina. Buenos Aires: Siglo XXI

(2007). Conflictos de la memoria en la Argentina. Un estudio histórico de la memoria social. PÉROTIN-DUMON, Anne (dir.), Historizar el pasado vivo en America Latina. Disponible en: http://americo.usal.es/iberoame/sites/default/ files/vezzetti_conflictos_memoria_argentina.pdf [acceso: 7 de julio de 2019]

VVAA (2000). Revista Punto de vista, 68.

ARFUCH, Leonor. Arte, memoria y archivo (pp. 34-37).

HUYSSEN, Andreas. El Parque de la Memoria. Una glosa desde lejos (pp. 25-28).

RICHARDS, Nelly. Memoria, fotografía y desaparición: drama y tramas (pp. 29-33). 
SCHMUCLER, Héctor. Las exigencias de la memoria (pp. 5-9).

SILVESTRI, Graciela. En arte en los límites de la representación (pp. 18-24). TERÁN, Oscar. Tiempos de memoria (pp. 10-12).

VEZZETTI, Hugo. Representaciones de los campos de concentración en la Argentina (pp. 13-17). 